\title{
THE COMMON HAMSTER AS A SYNURBIST: A HISTORY OF SETTLEMENT IN EUROPEAN CITIES
}

\author{
Natalia Yu. Feoktistova ${ }^{1}$, Alexey V. Surov ${ }^{1}$, Nikolay \\ N. Tovpinetz ${ }^{2}$, M.V. Kropotkina ${ }^{1}$, Pavel L. Bogomolov ${ }^{1}$, \\ Carina Siutz 3 , Werner Haberl ${ }^{4}$, Ilse E. Hoffmann ${ }^{3} *$
}

\author{
${ }^{1}$ Severtsov Institute of Ecology and Evolution, Russian Academy of Sciences, \\ Leninsky pr., 33, Moscow, 119071, Russia \\ ${ }^{2}$ National Epidemiological Center of Crimea, Naberejnaya, 67, Simferopol, \\ Crimea, 95034, Ukraine \\ ${ }^{3}$ Department of Behavioural Biology, University of Vienna, Althanstr. 14, 1090, \\ Vienna, Austria \\ ${ }^{4}$ Ökoteam - Institute of Animal Ecology and Landscape Planning, Bergmanng. \\ 22, 8010, Graz, Austria \\ * Corresponding author: ilse.hoffmann@univie.ac.at
}

\begin{abstract}
Following the expansion of agriculture in the Neolithic period, the common hamster has spread throughout Europe, and occurred abundantly until the recent past. However, in the last 45 years, populations declined markedly, partly attributable to urbanization and to major changes in agricultural practices. As a result, the species has been considered endangered at international levels as well as in most European countries. At the same time, the species has established populations in large Central and Eastern-European cities such as Vienna (Austria), Simferopol (Ukraine) and Nalchik (Russia), where it inhabits green spaces such as parks, gardens, embankments and buffer strips. In an attempt to reveal factors enabling hamsters to cope with urban environments, we reviewed historical data and habitat conditions of several urban hamster populations. We suggest that supplemental food resources and reduced predation pressure were the main factors promoting urban occurrence of common hamsters in the last 30 years. Its notable adaptability may be associated with higher stress resilience, ecological opportunism, polyphagy and higher fertility compared to species
\end{abstract}

Contribution of 26th Meeting of the International Hamster Workgroup, 15-17th November 2013, Poznań, Poland 
relying on non-urban habitats. The phenomenon of synurbization implies coexistence of wildlife and our urban civilization, but at the same time conflicting interests in conservation and urban development. Thus, the common hamster might serve as a model species for efficient mitigation and compensation concepts in urbanism and spatial planning.

Keywords: Cricetus cricetus, urbanization, adaptation, urban population

\section{INTRODUCTION}

The fundamental aim of ecology is to increase understanding of how organisms interact with the biotic and abiotic environment rather than address a particular societal, conservational or economical problem. From this point of view, Sutherland et al. (2013) highlighted 100 fundamental ecological questions including: "what determines whether species adapt, shift their ranges or go extinct?" Urbanization is a unique and evolutionarily new phenomenon and it has no natural analogues. Many bird and mammal populations have colonized cities, and some of them are much more successful in urban conditions than in their native natural habitats (LUNIAK 2004). Among mammals, rodents in particular have adapted well to live in cities, for example the brown rat (Rattus norvegicus) and mice (Apodemus spp., Mus musculus). These rodents proved successful by taking advantage of their synanthropic existence, which allowed them to expand their habitats over most parts of the world (KuCHERUK 1988). This phenomenon was termed "synurbization" (e.g., ANDRZEJewski et al.1978, BABiŃSKa-Werka et al. 1979, BabińsKa-Werka and Malinowska 2008), denoting the adjustment of wild animal populations to specific conditions of urban environments (LuniaK 2004). In some cases, animals seem to be attracted by abundant resources such as food or nest sites available in urbanized areas. On the other hand, they may subsequently suffer increased mortality rates due to anthropogenic impacts or novel diseases (e.g., LuniaK 2004, Rutz 2008). Evans et al. (2010) described three stages of the urban colonization process: arrival in the urban areas, adjustment to the urban environment and spreading within urban areas and to neighboring towns and cities. Adaptation to urban ecological niches requires changes in the behavior and ecology of synurbic populations in comparison with rural ones (e.g., Luniak 2004, BABIŃSKA-WERKA and Malinowska 2008, Surov and Tovpinetz 2008, Surov and Bogomolov 2013).

The common hamster (Cricetus cricetus) primarily inhabits fertile steppe and open grassland habitats, and was wide-spread from Belgium across Central Europe, Western Siberia, and North Kazakhstan to the upper Yenisei and Altai region and North Western China (Wilson and Reeder 2005, Sмith et al. 2008). As a classical synanthrope species („Kulturfolger” sensu PovolnÝ and ŠUSTeK 1982), it has successfully spread into a variety of anthropogenic habitats including meadows, croplands (especially cereals), field edges, road verges and scrubby fallow areas on farms. In the eastern part of its range, it frequently 
occurs in gardens and orchards, in close proximity to human habitation, and is more abundant in these man-made habitats than in its native grasslands. Its diet mainly consists of the green parts of plants and seeds, supplemented by invertebrates and, occasionally, small vertebrates. At high densities, it has been considered an agricultural pest (KrYštufek et al. 2008, Nechay 2000), as described by HANÁK Ker (1853): „... in 1769 they reached such a high number that they were killed in hundreds in the fields. The village Cseged gave up about 1,500 furs to Kassa" (now Košice, Slovakia; cited in Nechay 2000).

In the last 45 years, common hamster abundance has declined markedly throughout its range (NEUMANN et al. 2005). At the same time, numbers increased in several urban agglomerations from Russia to Germany (e.g., ČANÁDY 2013, Franceschini-Zink and Millesi 2008, Schmelzer and Millesi 2008, Telitsina et al. 1994, Tovpinetz et al. 2006, Vohralík 2011). During the past decades, common hamsters have settled in gardens, cemeteries, parks and even buildings, and eventually established high-density and stable populations. On the other hand, peripheral hamster populations declined or even disappeared as a consequence of habitat destruction due to urban sprawl (Hoffmann 2011, Telitsina et al. 1994; V. Vohralík, personal communication).

Ground-dwelling rodents are generally classic subjects for research on population dynamics and population ecology (e.g., Boonstra 1994, FRANCESCHINIZiNK and Millesi 2008, SinClair 1989), in particular while facing habitat alterations (e.g., Andrzejewski et al. 1978, Babińska-Werka et al. 1979, BabińsKaWerka and Malinowska 2008, Kucheruk 1988, Surov and Bogomolov 2013). In the common hamster, the degree of interaction with human environments goes beyond that previously described for other endangered rodents (BANASZEK and Ziomek 2010, ČanÁdy 2013, Hoffmann 2011, Surov and Tovpinetz 2008, Telitsina et al. 1994, TovpinETZ et al. 2006). For this reason, research on urban populations of this species could provide substantial information about how synurbic mammals cope with the constraints imposed by altered environmental conditions.

Synurbic populations show ecological and behavioral differences as compared with populations of the same species living in their natural, non-urban habitats. In this paper, we aim to review the temporal occurrence of common hamsters in European cities from Russia to Germany and discuss some of the most typical features of synurbization according to LUNIAK (2004): high population density, altered circadian activity, adaptations of diet to supplemental food resources, tolerance toward anthropogenic structures and genetic modifications. Concluding, we outline possible costs and benefits associated with settling in novel types of environment.

\section{MATERIAL AND METHODS}

We examined data on the historical and recent occurrence of common hamsters close to human habitations from published papers, secondary sources, conference proceedings, online sources, reports, theses, our own unpublished data and personal communications. We compiled data gathered and published 
between 1977 and 2013, aiming to outline a review on the formation of synurbic common hamster populations in Europe as extensive as possible, proceeding from the East to the West.

\section{RESULTS AND DISCUSSION}

\section{Urban occurrence of common hamsters}

\section{$\underline{\text { Russia }}$}

The first records of common hamsters in Moscow (Table 1) date back to the end of the $19^{\text {th }}$ century (KARASEVA et al. 1999), referring mainly to river banks, ravine slopes with bushy vegetation and other semi natural habitat. The largest colonies in the region were found in the south-east of Moscow, in the Lyublino and Lyubertsy sewage treatment fields. Wastewater accumulated in the ponds, separated by earthen ramparts $10-12 \mathrm{~m}$ wide and $2 \mathrm{~m}$ high. Due to high humidity, these banks were covered with bushes and grass and hence were favorable habitats for many rodents and common hamsters in particular. The Moscow Rodent Control Service surveyed this rodent population from 1963 to 1993 by trapping animals twice a year (autumn and spring). In 1985, the treatment plant was closed, and housing blocks were densely built on the area in the 1990s (Telitsina et al. 1994). Hence, these large hamster colonies in Moscow have diminished or disappeared. At present, the common hamster has survived only in the southern part of Moscow where it has been confined to the valleys of small tributaries of the Moscow River. The actual number of animals in the city is unknown. Until 2013, the species was included in the Red Book of Moscow City (2001), but was excluded from the latest edition (2013) (Moscow city government regulation \#79 February, 19, 2013). As the landscape around Moscow currently does not contain habitat suitable for hamsters, the nearest recent occurrence of the species is located in the Ryazan region, $200 \mathrm{~km}$ to the South. Molecular genetic analysis revealed that Moscow haplotypes match with matrilines from that region (FеоктіsTova et al. 2013), indicating connectivity in the past.

There is evidence that the species has been common in Nalchik (Table 1), the capital of Kabardino-Balkaria, since the 1960s. According to sightings and the presence of inhabited burrows, unknown numbers still are widespread, mostly dwelling in private fruit and vegetable gardens throughout the city, in the large city park and around multistory buildings surrounded by shrubs and flower beds (F. Tемвотоva, personal communication).

\section{$\underline{\text { Ukraine }}$}

While the common hamster had become rare in natural habitats in Crimea by 2000 , it was recorded in eight cities and six towns of the Crimean peninsula in 2000-2004 (Tovpinetz et al. 2006). Over the subsequent eight years, it became even more widespread in human settlements and has been observed in 18 cities and 42 towns of the Crimean peninsula (Fеоктіsтova et al. 2013) including its 
THE COMMON HAMSTER AS A SYNURBIST

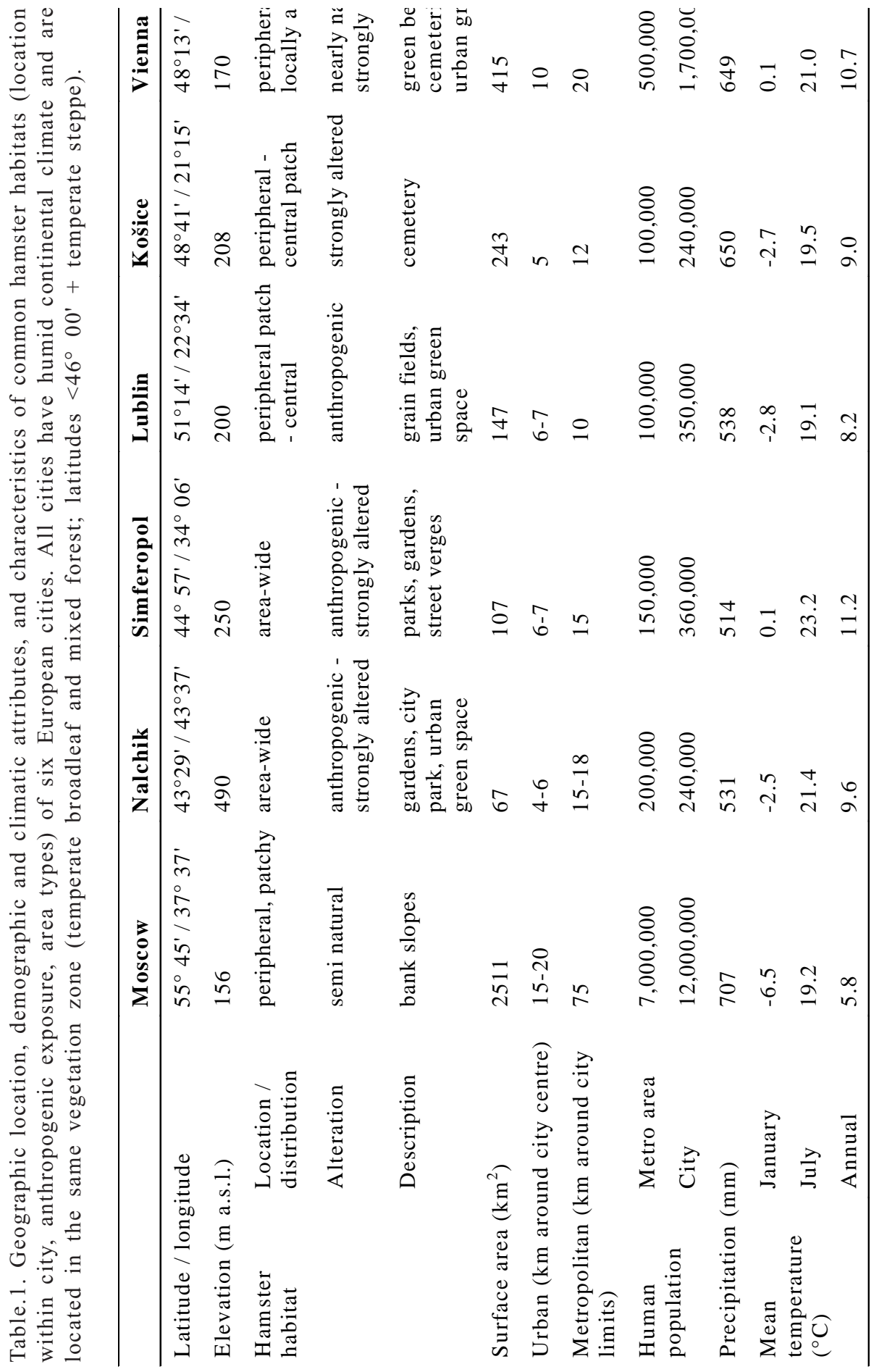


capital Simferopol (Table 1), where its presence has been reported since the late 1970s (Tovpinetz and Alexeev 1992). Persistent colonies of hamsters not only occur on the periphery, but also in the center of Simferopol: During a survey in 2000, they were found in 13 localities within the city. Average burrow density around one of the central streets (Sevastopolskaya) was 36 per hectare in 2000 (corresponding to approx. 12 individuals per hectare when abandoned burrows were excluded) and 26 burrows per hectare in another survey conducted in 2012. Whereas burrow entrances occasionally lead into basements and underground public utilities of houses, the majority of burrows, however, were found under trees and shrubs (FEOKTisTova et al. 2013).

\section{Poland}

In 2005, common hamsters were localized in the grain fields of an experimental station of the Agricultural University of Lublin (Table 1) in the district Felin. BANASZeK and ZIOMEK (2010) reported 73 active burrows and a population density of approximately 2.8 individuals per hectare between 2005 and 2008. The species' presence in urban parts of Lublin has been confirmed thereafter (LOPUCKI and Szeląg 2011).

\section{$\underline{\text { Slovakia }}$}

In 1971-1972, the common hamster was found in 192 Slovakian villages, suburbs and even the centers of cities such as Sobrance, Mihalovtse, Trebišov, Velke Kapushany and Košice, as long as there were no pest control activities (Grulich 1977). Since 2009, the common hamster has recurred in the southern part of Košice (East Slovakia) after cessation of pest control in the 24 ha Public Cemetery (ČANÁDY 2013). In 2012, a total of 15 individuals and 33 burrow systems were observed in the park-like cemetery area (Č́ANÁDY 2013).

\section{$\underline{\text { Austria }}$}

The largest populations of the common hamster in Central Europe inhabit Vienna (Table 1). They are virtually relics and have been investigated since 1995 (Schmelzer and Millesi 2008). After having maintained low densities for decades (personal observation), the population south of the Danube started to grow and thrive in the $1980 \mathrm{~s}$, coinciding with the termination of excessive application of rodenticides. In 2010, around 3,000 individuals dwelled in the outer green belt, cemeteries, parks and gardens down to embankments and street verges, and average density was 2.2 burrows per hectare (HofFmanN 2011). While Viennese „city-hamsters" rely on urban green patches in the order of $1000 \mathrm{~m}$. and thus mathematically achieve population densities of $20 / \mathrm{ha}$, the largest continuous habitats comprise 360 ha of the southeastern green belt with ca 250 burrows, and the 253 ha main cemetery with a projected 965 burrows. Another extreme is a renaturalized area along the S1 highway, where two dozen individuals could be found locally on less than one hectare (Hoffmann 2011). It should be noted, however, that these figures present solely a snapshot, since 
populations may fluctuate even within one season (natality, dispersal), and mortality in severe winters apparently strongly exceeds that of mild ones (Franceschini-ZinK and Millesi 2008).

\section{Czechia}

In 1976-1982, the common hamster occurred in Brno. While it was not abundant in the urban area, larger numbers were found in the unwooded, open countryside southeast of the town (PELIKÁn et al. 1983). During the $20^{\text {th }}$ century, hamsters were common in fields with heavy layers of loess soils at the northeastern periphery of Prague. Spacious housing estates composed by blocks of high panel-buildings were erected in the 1970s, leaving large grassy plots in between. At present, this so called Severní Město (= North Town) has ca 100,000 inhabitants. Common hamsters survived there, mostly in ruderal plots as well as in grassy areas, where the vegetation is cut (VoHRALík 2011). The species is also present in the western and southeastern suburbs where it inhabits abandoned fields, gardens and grassy plots in housing estates (V. VOHRALíK, personal communication).

\section{Germany}

Niethammer (1982) first mentioned records of common hamsters in lawns of cemeteries, gardens and parks of urban agglomerations in Germany. Currently, populations are known from the suburbs and peripheries of a few major cities such as Mainz, Mannheim, Hanover, Frankfurt, Göttingen and Braunschweig, where it occurs in the western parts with an estimated density of 0.3-3.0 burrows per hectare (Endres and Weber 1999, Kupfernagel 2003, Thorns 1998).

\section{Potential factors facilitating synurbism}

All of the above mentioned cities are situated within the historic range of the species (KRYŠTUFEK et al. 2008); with formerly only small populations in the Moscow area on the northern edge of the distribution range (Weinhold 1999). Despite the fact that some of them are considerably remote from each other (e.g., linear distance Moscow - Göttingen: 1,900 km) they have a similar, more or less continental, climate (Table 1), warm and humid with mild winters. The only exception is Moscow, where the climate is notably colder.

The common hamster inhabits fertile steppe and forest-steppe habitats, as well as in agricultural clearings in and near forest. Hence, its current range generally coincides with agricultural areas. In cities, it occurs in green spaces such as parks, cemeteries, gardens, embankments and buffer strips (Surov et al. 2013), which are often planted with adventive shrubs and trees. Hamsters are more or less polyphagous and thus forage on a variety of food species and types. In natural habitats in Poland, the diet mainly consisted of green parts and seeds of wheat and poppy (45\%), clover, rape, beet, maize, lucerne and occasionally invertebrates (6.2\%; GóRECKI and GRYGIELSKA 1975). In cities, ornamental plants and fruit trees provide supplemental high quality food such as blossoms, fruits and seeds of chestnut, sycamore, plum, honey locust, oak, walnut, 
filbert, rowan, arrow-wood, pear, apple and cherry (Surov et al. 2013), and vegetables (e.g., potatoes, corn and beans; Tovpinetz at al. 2006). Field observations confirmed that common hamsters foraged on seeds and parts of Setaria spp., Tilia platyphyllos, T. cordata and, most likely, Thuja occidentalis (PELIKÁn et al. 1983), and when available, females preferably cached fruits of apple, chestnut and cherry (Hufnagl et al. 2011). In cities, trees and bushes are often watered, which may increase food resources during drought, while garbage, dumps and human stores may be available for hamsters ad libitum. For example, discarded leftovers were frequently found in urban areas of the Viennese district with the highest hamster population densities, which could explain their accumulation just there (HofFmAnN 2011).

Substrate with preferably heavy layers of loam and loess (WEINHOLd 1999) are a prerequisite for burrowing activities of hamsters. High population densities and abundance in Simferopol, Vienna and Prague may have been promoted by an optimal substrate, increasing the availability of numerous and stable burrow systems.

Due to the permanent presence of humans, urban hamsters are rarely exposed to potential predators such as kestrels (Falco tinnunculus), owls (e.g., Bubo bubo; Spitzenberger and Bauer 2001), red foxes (Vulpes vulpes), and its main mammalian predators (Niethammer 1982), various mustelids (Mustela eversmanii, M. putorius, M. erminea, Vormela peregusna, Martes foina; Siutz and Millesi 2012). However, dogs and cats locally substituted for the original predators: In Simferopol, we observed stray dogs to prey upon hamsters (unpublished data) whereas in Vienna, dogs are kept as more or less restrained pets and thus rarely cause harm. Cats may also pose a danger, mainly for juveniles and subadults. The brown rat (Rattus norvegicus) is a potential competitor, but may also be a predator of the hamster. FrAnCESChini and Millesi (2007) observed rats attacking hamsters (mostly young ones) and competing for food, both most probably resulting from an elevated stress response.

\section{Behavioral adaptations to urban environments}

Although the common hamster is typically nocturnal (Niethammer 1982), it exhibited diurnal surface activity in Vienna (Schmelzer and Millesi 2003) as well as in Simferopol (Tovpinetz et al. 2006). As hamster burrows were located close to the main street of Simferopol, animals did not seem to avoid disturbance by traffic and illumination.

In the Altay foothills, a natural habitat, fierce male-male fights were recorded from May to June (KARASEVA 1962). Information about aggression of the common hamster in urban areas is mainly available for Vienna (e.g., FrANCESCHINI et al. 2007), where most aggressive interactions between males occur in April and May, the peak mating period. Thereafter, almost no intra-sexual interactions were observed (FRANCESCHINI et al. 2007). The situation after male reproduction season compares to Simferopol, where males sniffed each other and separated peacefully, or even entered the same burrow. However, reduced agonistic behavior in Simferopol was observed in August, after the end of the mating period 
(Lebl and Millesi 2008). Females did not seem aggressive in August as well, and they were more active than males, foraging to accumulate sufficient fat reserves and caches. Females were obviously less fat and some had pups, both of which might have stimulated their foraging behavior. Their average run per day was seven times larger than in males, which spent more time grooming and burrowing. Neither the number of litters per female nor litter size differed significantly from populations in agricultural areas (KAYSER and Stubbe 2003).

\section{Genetics}

The question concerning possible genetic differences between synurbic and non-urban populations has no clear answer so far (LunIAK 2004). Interestingly, hamster populations in the cities we reviewed belong to at least three different genetic lineages ("Pannonia”, „East”, and "West”; cf. Neumann et al. 2005), all of which obviously inhere the potential for synurbism. Thus, adaptations to urban environments rather seem due to the phenotypic plasticity of the species. Still, genetic differences should be kept in mind when preparing and conducting reintroductions.

\section{Agricultural pest vs endangered species}

Well into the $20^{\text {th }}$ century, the common hamster was locally so abundant in Europe that rural communities offered rewards for killed specimens (e.g., Wick 1934 in Spitzenberger 2001), and the fur trade flourished until the 1980s (Franke and Kroll 1989). Today, the species is considered endangered on international as well as on most national levels. However, responses of the public to its presence are still ambiguous, urban hamsters are often confused with rats and/or fell victim to deratizations. The increasing abundance of urban hamsters after pest control reduction (ČAnÁdy 2013, Grulich 1977, HoffmanN 2011) indicates that nonspecific applications of rodenticides locally has led to low population densities near to extinction. On the other hand, population peaks in urban environments, with hamsters foraging and burrowing in gardens and orchards, may produce conflicts between conservation concerns and land users (Hoffmann 2011). Informed public relations and mediation between conflicting interests of ecology and the general public is thus essential for efficient, practicable and publicly acceptable conservation measures.

\section{CONCLUSION}

Given that basic requirements are fulfilled, common hamsters apparently benefit from proximity to human habitations in general and synurbism in particular. In urban agglomerations, they have access to supplemental food and are less exposed to predators, thus facilitating the establishment of persistent high density populations. We assume that the species' ecological opportunism, polyphagy and higher fertility as compared to other hibernators have been crucial for the ability to settle in urban environments. However, among the cities reviewed, hamsters occur synurbic sensu stricto only in parts of Nalchik, 
Simferopol, Lublin and Vienna, in that they successfully dispersed into urban areas where they had not been recorded previously. All other populations mentioned inhabit suitable patches at the periphery or in suburbs, the latter of which had been natural or agricultural hamster habitat until the recent past (e.g., Moskow: Telitsina et al. 1994; Prague: Vohralík 2011). Even in Vienna, the largest continuous populations have been found to dwell at the periphery (Hoffmann 2011). Adaptability to different degrees of urbanization on a scale from nearly natural (e.g., outer green belts) to strongly altered (e.g., verges of main streets) and its genetic potential remain yet to be investigated.

The exposure to human impact is a substantial factor influencing the existence of wildlife in the urban landscape. On the other hand, artificially shaped areas might offer the opportunity to supply refuge areas and to manage the persistence of natural communities, provided that efficient conservation plans are implemented.

\section{Acknowledgments.}

The authors are deeply grateful to DR. F. Tемвотоva - director of the Institute of Ecology of Mountain Territories, RAS (Nalchik) - and to DR. V. VoHRALík for invaluable information on common hamster occurrence in Nalchik and Prague. Three anonymous reviewers are thanked for providing supportive comments on former drafts of the manuscript.

\section{CHOMIK EUROPEJSKI JAKO PRZYKLAD SYNURBIZACJI: HISTORIA ZASIEDLANIA MIAST EUROPEJSKICH}

\section{STRESZCZENIE}

Chomik europejski rozprzestrzenił się w Europie w następstwie rozwoju rolnictwa w Neolicie i do niedawna występował bardzo licznie. Jednak w ciągu ostatnich 45 lat, liczebność populacji wyraźnie spadła częściowo ze względu na urbanizację i znaczące zmiany w rolnictwie. W efekcie gatunek jest obecnie uważany za zagrożony zarówno na poziomie międzynarodowym, jak i w poszczególnych państwach europejskich. Jednocześnie jednak powstały populacje w dużych miastach Europy Centralnej i Wschodniej, na przykład w Wiedniu (Austria), Symferopolu (Ukraina) i Nalchiku (Rosja), gdzie chomik zamieszkuje tereny zielone takie jak parki, ogrody na nabrzeżach rzek i pasy buforowe. W celu ustalenia czynników umożliwiających chomikom dostosowanie do warunków zurbanizowanych, stworzyliśmy przegląd danych historycznych i warunków siedliskowych w kilku miejskich populacjach chomika. Sugerujemy, że dodatkowe źródła pokarmu i zmniejszony nacisk drapieżników były głównymi czynnikami sprzyjającymi występowaniu chomika europejskiego w miastach w ciągu ostatnich 30 lat. Szczególna adaptacyjność chomika może być związana z wyższą odpornością na stres, ekologicznym oportunizmem, wszystkożernością i wyższą płodnością w porównaniu do gatunków polegających na niezurbanizowanych siedliskach. 
Fenomen synurbizacji zakłada współistnienie przyrody i naszej miejskiej cywilizacji, ale w tym samym czasie przeciwstawne interesy ochrony i rozwoju urbanistycznego. Tak więc chomik europejski może posłużyć za gatunek modelowy dla idei skutecznego łagodzenia konfliktów i wyrównywania strat w urbanistyce i planowaniu przestrzennym.

\section{REFERENCES}

Andrzejewski R., Babińska-Werka J., Gliwicz J., Goszczyński J. 1978: Synurbization processes in population of Apodemus agrarius. I. Characteristics of populations in an urbanization gradient. Acta Theriol., 23: 341-358.

Babińska-Werka J., Gliwicz J., Goszczyński J. 1979: Synurbization processes in a population of Apodemus agrarius. II. Habitats of the striped field mouse in town. Acta Theriol., 24: 405-415.

Babińska-Werka J., Malinowska B. 2008: Synurbization of yellow-necked mouse Apodemus flavicollis in Warsaw. In: Fauna Miast Ochronic Rożnorodność Biologiczną w Miastach. Bydgoszcz, 634 p. (in Polish with English summary).

Banaszer A., Ziomek J. 2010: The common hamster (Cricetus cricetus L) population in the city of Lublin. Annales Universitatis Mariae Currie Sklodowska Lublin Polonia, 65 (1): 59-66.

Boonstra R. 1994: Population cycles in microtines: the senescence hypothesis. Evol. Ecol., 8: 196-219.

ČANÁDY A. 2013: New site of the European hamster (Cricetus cricetus) in the urban environment of Košice city (Slovakia). Zoology and Ecology, 23 (1): 61-65.

Endres J., Weber U. 1999: Möglichkeiten und Maßnahmen zur langfristigen Erhaltung des Feldhamsters (Cricetus cricetus L.) im Nordbereich der Universität Göttingen. Dokumentation zum Pilot-Forschungsprojekt "Feldhamster" am Institut für Wildbiologie und Jagdkunde der Georg-August-Universität Göttingen, 263 pp. (in German).

Evans K.L., Hatchwell B.J., Parnell M., Gaston K.J. 2010: A conceptual framework for the colonisation of urban areas: the blackbird Turdus Merula as a case study. Biological Review, 85: 643-667.

Feoktistova N., Meschersky I., Tovpinetz N., Kropotkina M., Surov A. 2013: A history of Common hamster (Cricetus cricetus) settling in European cities. Proceedings of the $20^{\text {th }}$ Meeting of the International Hamster Workgroup. The European hamster - new problems and prospects of their solution. Poznan, Poland: 17.

Franceschini C., Millesi E. 2007: Influences on population development in urban living European Hamsters (Cricetus cricetus). Proceedings of the $11^{\text {th }}, 14^{\text {th }}$, and $15^{\text {th }}$ meeting of the International Hamster Workgroup. Budapest, Hungary (2003), Münsterschwarzach, Germany (2006) and Kerkrade, the Netherlands (2007): 14-17.

Franceschini C., Siutz C., Palme R., Millesi E. 2007: Seasonal changes in cortisol and progesterone secretion in Common hamsters. Gen. Comp. Endocrinol., 152: 14-21.

Franceschini-Zink C., Millesi E. 2008: Population development and life expectancy in Common hamsters. Biosystematics and Ecology Series, 25: 45-59. 
Franke C., Kroll J. 1989: Jury Fränkel's Rauchwaren-Handbuch 1988/89.10 $0^{\text {th }}$ ed., Rifra, Murrhardt: 480 p. (in German).

Górecki A., Grygielska M. 1975: Consumption and utilization of natural foods by the Common hamster. Acta Theriol., 20, 18: 237-246.

Grulich I. 1977: A population outbreak of Cricetus cricetus (L.) in Eastern Slovakia during 1971-1972. Bjuleten Moscovskovo Obsestva Ispytateley Prirodi, Otdel Biologitseskij, 82 (6): 16-25 (in Russian with English summary).

Hoffmann I.E. 2011: Distribution of Common hamsters in Vienna. MA22-1422/2010, Municipal Department for Environmental Protection, 15 p. (in German with English abstract) plus map (www.wien.gv.at/umweltschutz/naturschutz/pdf/ feldhamster-karte.pdf).

Hufnagl S., Siutz C., Millesi E. 2011: Diet composition of Common hamsters (Cricetus cricetus) living in an urban habitat. Säugetierkdl. Inf., 8: 69-78.

Karaseva E.V. 1962: Study of home ranges of Common hamster in Altay by capturerecapture method. Zool. J., 41 (2): 275-285 (in Russian).

Karaseva E.V., Telitsina A.Yu., Samoilov B.L. 1999: Moscow mammals in the past and in the present. Nauka, IPEE: 244 p. (in Russian).

Kayser A., Stubbe M. 2003: Untersuchungen zum Einfluss unterschiedlicher Bewirtschaftung auf den Feldhamster Cricetus cricetus (L.), einer Leit- und Charakterart der Magdeburger Börde. Tiere im Konflikt, 7: 148 p. (in German).

Kryštufek B., Vohralík V., Meinig H., Zagorodnyuk, I. 2008: Cricetus cricetus. In: IUCN 2013. IUCN Red List of Threatened Species, Version 2013.2. $<$ Www.iucnredlist.org $>$.

KUCHERUK V.V. 1988: Rodents - the inhabitants of buildings and human settlements in different regions of the USSR. General and regional terriologiya. Nauka: 165-237.

Kupfernagel C. 2003: Raumnutzung umgesiedelter Feldhamster Cricetus cricetus (Linnaeus, 1758) auf einer Ausgleichsfläche bei Braunschweig. Braunschweiger Naturkundliche Schriften, 6 (4): 857-887 (in German).

Lebl K., Millesi E. 2008: Yearling male Common hamsters and the trade-off between growth and reproduction. In: E. Millesi, H. Winkler, R. Hengstberger R. [eds.] The Common hamster (Cricetus cricetus): Perspectives on an endangered species. Biosystematics and Ecology Series, 25: 115-126.

LUNIAK M. 2004: Synurbization - adaptation of animal wildlife to urban development. Proceedings $4^{\text {th }}$ International Urban Wildlife Symposium (W.W. SHaw, K.L. Harris, L. van Druff, eds.). Tucson, Univ. of Arizona: 50-55.

Łopucki R., SZeląg A. 2011: Urban and suburban populations of the common hamster: differences in density and habitat preferences. In: P. INDYKIEWICZ, L. JeRZAK, J. Bohner, B. Kavanagh [eds.] Studies of animal biology, ecology and conservation in European cities. UTP. Bydgoszcz: 525-532.

Moscow Government 2001: Red Data Book of the City of Moscow. $1^{\text {st }}$ ed., ABF: 622 p.

Povolný D., ŠUstek Z. 1982: An attempt at a methodical separation of the concepts „synanthrope” and „Kulturfolger”. Ekológia (CSSR), 1: 13-24.

Neumann K., Michaux J., Maak S., Jansman A.H., Kayser A., Mundt G., Gattermann R. 2005: Genetic spatial structure of European common hamsters (Cricetus cricetus) - a result of repeated range expansion and demographic bottlenecks. Mol. Ecol., 14: 1473-1483.

Nechay G. 2000: Status of hamster: Cricetus cricetus, Cricetulus migratorius, Mesocricetus newtoni and other hamster species in Europe. Nature and Environment series. Council of Europe Publishing, 106, Strasbourg: 73 p. 
Niethammer J. 1982: Cricetus cricetus (Linnaeus, 1758) - Feldhamster. In: J. Niethammer, F. KRAPP [eds.] Handbuch der Säugetiere Europas. Wiesbaden, Bd. 2/1, Rodentia II: 7-28 (in German).

Pelikán J., Zejda J., Homolka M. 1983: Mammals in the urban agglomeration of Brno. Acta Sc. Nat. Brno, 17 (9): 1-49.

Rusin M.Yu., Banaszek A., Mishta A.V. 2013: The common hamster (Cricetus cricetus) in Ukraine: evidence for population decline. Folia Zool., 62 (3): 207-213.

Rutz Сн. 2008: The establishment of an urban bird population. J. Anim. Ecol., 77: 1008-1019.

Schmelzer E., Millesi E. 2008: Surface activity patterns in a population of European hamsters (Cricetus cricetus) in an urban environment. In: G. Nechay [ed.] The Common Hamster in Europe. Ecology, management, genetics, conservation, reintroduction. Proceedings Meeting of the International Hamster Workgroup: 19-22.

Sinclair A.R.E. 1989: Population regulation in animals. In: J.M. Cherrett [ed.] Ecological concepts. Blackwell, Oxford: 197-241.

Siutz C., Millesi E. 2012: Effects of birth date and natal dispersal on faecal glucocorticoid concentrations in juvenile Common hamsters. Gen. Comp. Endocrinol., 178: $323-329$.

Smith A.T., Xie Y., Hoffmann R.S., Lunde D., MacKinnon J., Wilson D.E., Wozencraft W.C. [eds.] 2008: A Guide to the Mammals of China. Princeton University Press, Princeton: $247 \mathrm{p}$.

Spitzenberger F., Bauer K. 2001: Hamster Cricetus cricetus (Linnaeus, 1758). In: F. Spitzenberger, [ed.] Die Säugetierfauna Österreichs. Grüne Reihe des Bundesministeriums für Land- und Forstwirtschaft, Umwelt und Wasserwirtschaft, 13: 406-415 (in German).

Surov A.V., Bogomolov P.L. 2013: Tendencies in the dynamics of the fauna of small mammals under conditions of changing urban environment. Proceedings of the $1^{\text {st }}$ Eurasian Pest Management Conference, Moscow, Institute of Pest Management: $274-278$.

Surov A., Feoktistova N., Tovpinetz N., Siutz C., Hoffmann I. 2013: Comparison of Common hamster (Cricetus cricetus) habitats in Vienna (Austria) and Simferopol (Ukraine). Proceedings of the $20^{\text {th }}$ Meeting of the International Hamster Workgroup. The European hamster - new problems and prospects of their solution. Poznan, Poland: 34.

Surov A.V., Tovpinetz N.N. 2008: Population of Common hamster in Simferopol (Ukraine): fast formation of synanthropic adaptations. Proceedings of the $11^{\text {th }}, 14^{\text {th }}$, and $15^{\text {th }}$ meeting of the International Hamster Workgroup: Budapest, Hungary (2003), Münsterschwarzach, Germany (2006) and Kerkrade, the Netherlands (2007): 17.

Sutherland W.J., Freckleton R.P., Godfray H.C.J., Beissinger S.R., Benton T., Cameron D.D., Carme Y., Coomes D.A., Coulson T., Emmerson M.C., Hails R.S., Hays G. C., Hodgson D.J., Hutchings M.J., Johnson D., Jones J.P.G., Keeling M.J., KoKko H., Kunin W.E., Lambin X., Lewis O.T., Malhi Y., Mieszkowska N., Milner-Gulland E.J., Norris K., Phillimore A.B., Purves D.W., Reid J.M., Reuman D.C., Thompson K., Travis J.M.J., Turnbull L.A., Wardle D.A., Wiegand T. 2013: Identification of 100 fundamental ecological questions. J. Ecol., 101 (1): 58-67.

Telitsina A.Yu., Karaseva E.V., Stepanova N.V., Surov A.V. 1994: Common hamster in Moscow. Rodent's synanthropy. Materials of the $2^{\text {nd }}$ meeting, Ivanovo: 92-100 (in Russian). 
Thorns, H.-J. 1998: Die Göttinger Feldhamster-Story. BUND Landesverband Niedersachsen e.V., BUNDmagazin, 4: www.bund-niedersachsen.de/service/bundmagazin/ (in German).

Tovpinetz N.N., Alexeev A.F. 1992: Distribution and ecology of the common features of the hamster in the Crimea. Rodent's synanthropy and rodent control. Moscow, IPEE: 393-407 (in Russian).

Tovpinetz N.N., Evstafiev I., Karaseva E. 2006: Habitude to synanthropy of common hamster (Cricetus cricetus) based on investigations in the Crimea. Fauna in anthropogenic environments. Luhansk, Ukraine: 136-145 (in Russian).

Vohralík V. 2011: New records of Cricetus cricetus in the Czech Republic (Rodentia: Cricetidae). Lynx, n.s. (Praha), 42: 189-196 (in Czech with English summary).

Weinhold U. 1999: Cricetus cricetus (Linnaeus, 1758). In: A.J. Mitchell-Jones, G. Amori, W. Bogdanowicz, B. Kryštufek, P.J.H. Reijnders, F. Spitzenberger, M. Stubbe, J.B.M. Thissen, V.Vohralík, J. Zima [eds.] The Atlas of European Mammals. Academic Press, London: 202-203.

Wilson D.E., Reeder D.A.M. 2005: Mammal Species of the World. A Taxonomic and Geographic Reference. $3^{\text {rd }}$ ed. V. 2. Baltimore, The J. Hopkins University Press: 2142 p. 